\title{
$N$-Acetyltaurine dissimilated via taurine by Delftia acidovorans NAT
}

\author{
Jutta Mayer - Karin Denger · Theo H. M. Smits • \\ Klaus Hollemeyer · Ulrich Groth · Alasdair M. Cook
}

\begin{abstract}
The naturally occurring sulfonate $N$-acetyltaurine was synthesized chemically and its identity was confirmed. Aerobic enrichment cultures for bacteria able to utilize $N$-acetyltaurine as sole source of fixed nitrogen or as sole source of carbon were successful. One representative isolate, strain NAT, which was identified as a strain of Delftia acidovorans, grew with $N$-acetyltaurine as carbon source and excreted stoichiometric amounts of sulfate and ammonium. Inducible enzyme activities were measured in crude extracts of this organism to elucidate the degradative pathway. Cleavage of $\mathrm{N}$-acetyltaurine by a highly active amidase yielded acetate and taurine. The latter was oxidatively deaminated by taurine dehydrogenase to ammonium and sulfoacetaldehyde. This key intermediate of sulfonate catabolism was desulfonated by the known reaction of sulfoacetaldehyde acetyltransferase to sulfite and acetyl phosphate, which was further degraded to enter central metabolism. A degradative pathway including transport functions is proposed.
\end{abstract}

Keywords Sulfoacetaldehyde acetyltransferase · Xsc $\cdot$ Amidase $\cdot$ Desulfonation

J. Mayer · K. Denger · T. H. M. Smits · A. M. Cook $(\square)$

Fachbereich Biologie der Universität Konstanz,

78457 Konstanz, Germany

e-mail: Alasdair.Cook@uni-konstanz.de

U. Groth · J. Mayer

Fachbereich Chemie der Universität Konstanz,

78457 Konstanz, Germany

K. Hollemeyer

Institut für Technische Biochemie, Universität des

Saarlandes, PO Box 151150, 66041 Saarbrücken, Germany

\section{Introduction}

$\mathrm{N}$-Acetyltaurine (Fig. 1) is secreted by orb spiders in molar concentrations in the viscid droplets applied to their webs as one component of the complex mechanism to catch prey (Vollrath et al. 1990; Higgins et al. 2001); the compound is thus widespread in Nature. The compound is usually the major, low molecular-weight species present on these webs, and it is one of the many derivatives of taurine (2-aminoethanesulfonate) found in Nature (Huxtable 1992). The bacterial transformations of taurine are very diverse (Cook and Denger 2006), but much less is known about the transformation of taurine derivatives and analogues (Cook and Denger 2002; Weinitschke et al. 2006).

Taurine (two routes), isethionate, sulfoacetate and ethane-1,2-disulfonate are all converted to sulfoacetaldehyde, which is subject to phosphatolysis to acetyl phosphate and sulfite by sulfoacetaldehyde acetyltransferase (Xsc) [EC 2.3.3.15]; three subgroups of sulfoacetaldehyde acetyltransferases are currently known (Denger et al. 2001; Cook and Denger 2002; Ruff et al. 2003; Brüggemann et al. 2004; Denger et al. 2004a). The only taurine derivative, whose complete degradative pathway has been elucidated, $N$-methyltaurine, is converted directly to sulfoacetaldehyde and methylamine by ( $N$-methyl)taurine dehydrogenase (Tdh) [EC 1.4.2.-] in Alcaligenes spp. and Paracoccus spp. (Weinitschke et al. 2006). Taurocholate, a bile salt, is cleaved by bile salt hydrolases [EC 3.5.1.24] (e.g. Kim et al. 2004) to taurine and cholate, whose degradative path is unknown. $N$-acetyltaurine is known to be a substrate for a different amidase, hog-kidney $N$-acetyl- $\beta$-alanine deacetylase [EC 3.5.1.21] (Fujimoto et al. 1968). 


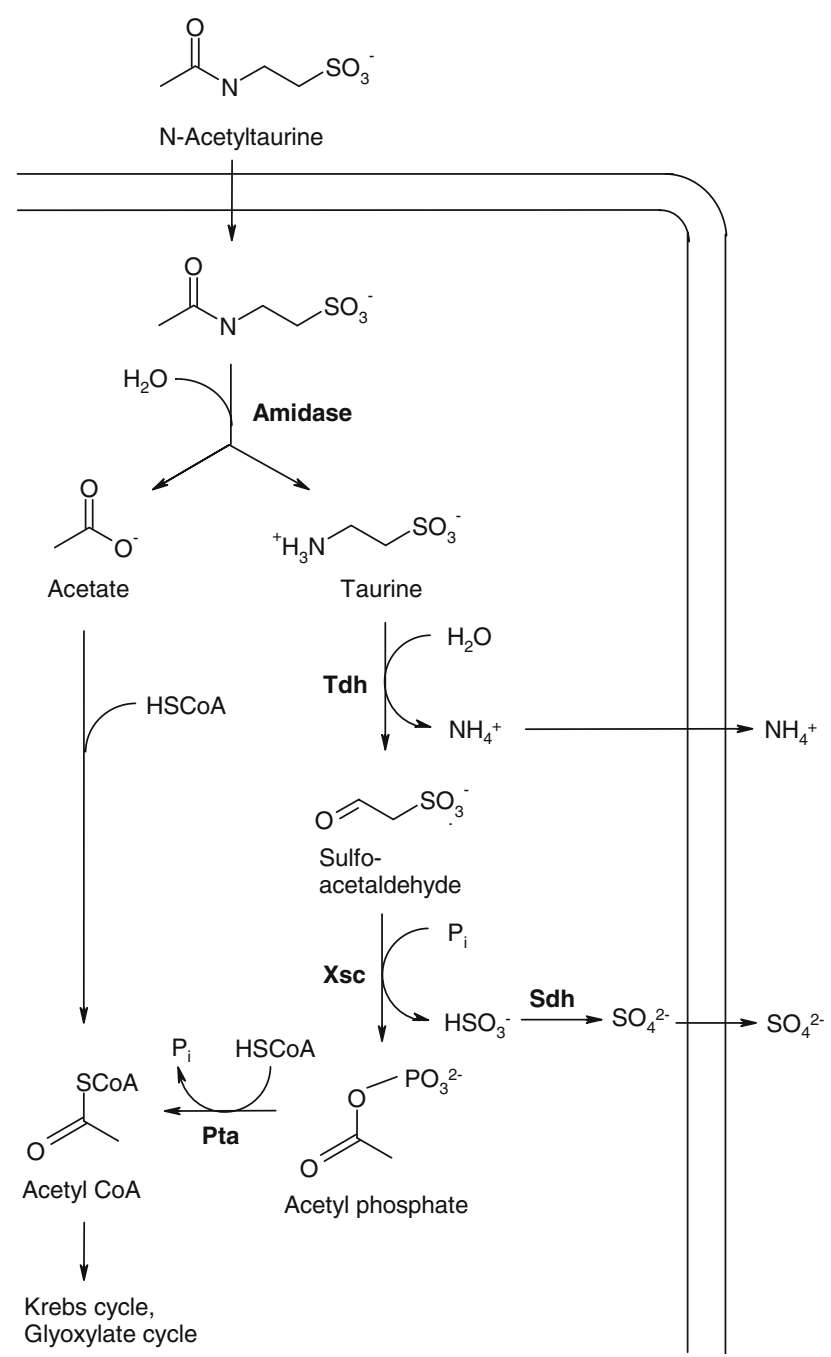

Fig. 1 Proposed dissimilatory pathway for $N$-acetyltaurine in Delftia acidovorans NAT. A transport system for the charged $N$-acetyltaurine can be predicted (Cook and Denger 2002). The amidase was found in the present paper, as were three typical enzymes of taurine catabolism (Cook and Denger 2006) taurine dehydrogenase (Tdh), sulfoacetaldehyde acetyltransferase (Xsc) and phosphotransacetylase (Pta). A representative enzyme of the glyoxylate pathway, isocitrate lyase, was also detected (Table 1). Candidates for export functions are AmtB for ammonia (Denger et al. 2006; Gorzynska et al. 2006) and OrfX for sulfate (Rein et al. 2005)

A hypothetical degradative pathway for $N$-acetyltaurine has many components. A transporter for the substrate with its charged sulfonate group is essential (Fig. 1). Cleavage of $N$-acetyltaurine to acetamide and sulfoacetaldehyde (not shown) or hydrolysis to taurine and acetate (Fig. 1) can be hypothesized. Taurine dissimilation via Tdh [EC 1.4.2.-] (Brüggemann et al. 2004) or via taurine:pyruvate aminotransferase and alanine dehydrogenase (e.g. Denger et al. 2004a) requires an export function to remove excess ammonium ion (e.g. Brüggemann et al. 2004), while the follow-up
Table 1 Enzyme activities (mkat $(\mathrm{kg} \text { protein })^{-1}$ ) of crude extracts of Delftia acidovorans NAT under different growth conditions

\begin{tabular}{llll}
\hline Enzyme & $\begin{array}{l}\text { Acetate } \\
\text { grown }\end{array}$ & $\begin{array}{l}\text { Taurine } \\
\text { grown }\end{array}$ & $\begin{array}{l}\text { NAT } \\
\text { grown }\end{array}$ \\
\hline $\begin{array}{l}N \text {-acetyltaurine } \\
\text { amidase EC 3.5.1.- }\end{array}$ & 0.5 & 0.3 & 39 \\
$\begin{array}{l}\text { Taurine dehydrogenase } \\
\text { EC 1.4.2.- }\end{array}$ & BLD & 0.27 & 0.08 \\
$\begin{array}{l}\text { Taurine:pyruvate aminotransferase } \\
\text { EC 2.6.1.77 }\end{array}$ & BLD & BLD & ND \\
$\begin{array}{l}\text { Sulfoacetaldehyde acetyltransferase } \\
\quad \text { EC 2.3.3.15 }\end{array}$ & BLD & 2.5 & 1 \\
$\begin{array}{l}\text { Phosphate acetyltransferase } \\
\quad \text { EC 2.3.1.8 }\end{array}$ & 0.8 & 0.2 & 0.2 \\
$\begin{array}{l}\text { Sulfite dehydrogenase } \\
\quad \text { EC 1.8.2.1 }\end{array}$ & 1.3 & 34 & 78 \\
$\begin{array}{l}\text { Isocitrate lyase } \\
\text { EC 4.1.3.1 }\end{array}$ & 1.3 & 1.7 & 1.7 \\
\hline
\end{tabular}

$N A T N$-acetyltaurine, $N D$ not determined, $B L D$ below the limit of detection. The limits of detection for Tdh, Tpa and Xsc were $0.02,0.5$ and 0.3 mkat $(\mathrm{kg} \text { protein })^{-1}$, respectively

of desulfonation by Xsc is the need to remove sulfite, usually as sulfate, so both a sulfite dehydrogenase [EC 1.8.2.1] and a sulfate exporter are needed. A putative protein, OrfX, which belongs to the large group of putative membrane proteins with domains of unknown function (DUF81), has been proposed for this function in $\beta$-Proteobacteria (all Burkholderiales) (Rein et al. 2005; Cook and Denger 2006). The acetate generated from $N$-acetyltaurine will need activation, effectively to acetyl-CoA, such that acetyl-CoA from both $\mathrm{C}_{2}$-moieties of $\mathrm{N}$-acetyltaurine can be processed via the Krebs cycle and, in $\beta$-Proteobacteria, the glyoxylate shunt. Examination of these possibilities led to an hypothesis (Fig. 1), much of which was confirmed in this study.

\section{Materials and methods}

\section{Materials}

The sodium salt of $N$-acetyltaurine was synthesized on the gram scale in an $\mathrm{S}_{\mathrm{N}} 2$ reaction (e.g. Clayden et al. 2001) from taurine and acetic anhydride under alkaline conditions in ethanol (Teraoka 1925). The product was recrystallized in ethanol with a yield of 7\% (Lit.: 13\%). It gave a sharp melting point at $234^{\circ} \mathrm{C}$ (Lit.: $233-234^{\circ} \mathrm{C}$ ). The product, a white powder, was highly soluble in water, as described previously (Teraoka 1925), and neither acetate nor taurine was detected in the product. Analysis by ${ }^{1} \mathrm{H}-\mathrm{NMR}$ (400 MHz, DMSO) gave the following data: $\delta$ [ppm] 
$1.76\left(3 \mathrm{H} ; \mathrm{s} ;-\mathrm{CH}_{3}\right), 2.57\left(2 \mathrm{H} ; \mathrm{t} ;{ }^{3} J=7.4 ;-\mathrm{CH}_{2}-\mathrm{SO}_{3}^{-}\right)$, $3.27\left(2 \mathrm{H} ; \mathrm{m} ; \mathrm{N}-\mathrm{CH}_{2}-\mathrm{C}\right)$ and $7.79(1 \mathrm{H} ; \mathrm{s} ;-\mathrm{NH}-)$. Analysis by ${ }^{13} \mathrm{C}-\mathrm{NMR}$ (400 MHz, DMSO) gave the following data: $\delta$ [ppm] $22.8\left(-\mathrm{CH}_{3}\right), 35.5\left(\mathrm{~N}-\mathrm{CH}_{2}-\right.$ C), $50.6\left(-\mathrm{CH}_{2}-\mathrm{SO}_{3}^{-}\right)$and $168.9(\mathrm{C}=\mathrm{O})$. Analysis by matrix-assisted laser-desorption ionization time-offlight mass spectrometry (MALDI-TOF-MS) in the negative ion mode $\left(m / z=166[M-1]^{-}\right)$confirmed the identity of the product $(M=167)$. The preparation of sulfoacetaldehyde, as the bisulfite addition complex, was described elsewhere (Denger et al. 2001). Commercial chemicals were of the highest purity available, and they were purchased from Fluka, Merck, Roth, Serva or Sigma.

Enrichment cultures, isolations, growth media, growth conditions and cell disruption

The salts medium for carbon-limited aerobic enrichment cultures $(5 \mathrm{ml}$ in $50 \mathrm{ml}$ tubes) was a $50 \mathrm{mM}$ potassium phosphate buffer, $\mathrm{pH} 7.2$, which contained $0.25 \mathrm{mM}$ magnesium sulfate, $20 \mathrm{mM}$ ammonium chloride and trace elements (Thurnheer et al. 1986). $N$-acetyltaurine $(5 \mathrm{mM})$ was added as sole source of carbon or omitted in negative controls. The inocula were from activated sludge from the waste-water treatment plant in Konstanz, Germany, from forest soil, or from garden soil. Inoculation left the cultures visibly turbid. Incubation at $30^{\circ} \mathrm{C}$ on a roller for 1-3 days showed negligible growth in the negative controls, and increased turbidity in the putative $\mathrm{N}$-acetyltaurine-degrading cultures. After three passages in fresh medium, cultures were plated on Luria-Bertani medium (Gerhardt et al. 1994), and common colony morphologies were picked to fresh selective medium. A culture was considered pure when three cycles of homogeneous plates followed by growth in selective liquid medium were attained.

Nitrogen-limited enrichments contained $\mathrm{N}$-acetyltaurine $(2 \mathrm{mM})$ as sole source of combined nitrogen. The carbon sources were $5 \mathrm{mM}$ glucose plus $10 \mathrm{mM}$ glycerol plus $7 \mathrm{mM}$ succinate. Each set of enrichments included controls containing either no added combined nitrogen or $2 \mathrm{mM}$ ammonium chloride. The inoculum for nitrogen-limited enrichments was shaken with $50 \mathrm{mM}$ potassium phosphate buffer, $\mathrm{pH}$ 7.2, centrifuged and decanted to remove any soluble nitrogenous material.

Growth of Delftia acidovorans NAT with $N$-acetyltaurine as sole source of carbon was followed in 20-ml cultures in 300-ml Erlenmeyer flasks shaken in a water bath at $30^{\circ} \mathrm{C}$. Samples were taken at intervals to measure turbidity and to determine the concentra- tions of acetate, taurine and the sulfite and sulfate ions. In order to quantify the amount of protein, ammonia and sulfate after growth with different initial concentrations of $N$-acetyltaurine $(0-5 \mathrm{mM})$, the medium was adapted to a reduced concentration of ammonium chloride $(0.5 \mathrm{mM})$. Cultures $(50 \mathrm{ml})$ of cells grown with $\mathrm{N}$-acetyltaurine, taurine or acetate as sole carbon source were used for enzyme assays after harvesting by centrifugation $\left(30,000 \mathrm{~g}, 15 \mathrm{~min}, 4^{\circ} \mathrm{C}\right)$, washing with $50 \mathrm{mM}$ potassium phosphate buffer, $\mathrm{pH}$ 7.2 and storage $\left(-20^{\circ} \mathrm{C}\right)$. Cell suspensions were disrupted by three to four passages through a chilled French pressure cell at $140 \mathrm{MPa}$. Debris was removed by centrifugation $\left(30,000 \mathrm{~g}, 15 \mathrm{~min}, 4^{\circ} \mathrm{C}\right)$. Crude extracts could be used immediately or stored frozen without loss of activity.

Enzyme assays

$\mathrm{N}$-Acetyltaurine amidase was assayed discontinuously as the $\mathrm{N}$-acetyltaurine-dependent formation of acetate and taurine at $30^{\circ} \mathrm{C}$. The reaction mixture $(1 \mathrm{ml})$ contained $50 \mu \mathrm{mol}$ potassium phosphate buffer, $\mathrm{pH}$ 7.2, $25 \mu \mathrm{mol} N$-acetyltaurine and $0.1-0.9 \mathrm{mg}$ protein with which the reaction was started. Samples were taken at intervals and the reaction stopped by the addition of (a) $\mathrm{NaHCO}_{3}$ for the determination of taurine by HPLC or (b) formic acid for the quantification of acetate by GC. The reaction was linear for at least $8 \mathrm{~min}$. The possible presence of ketoprofen-amide amidase was tested with two substrates (acetamide and valeramide) used in the work of Hayashi et al. (1997).

Taurine dehydrogenase was assayed spectrophotometrically with dichlorophenol indophenol (DCPIP) as the electron acceptor (Brüggemann et al. 2004). Beef-heart cytochrome $c$ could not replace DCPIP. Taurine:pyruvate aminotransferase (Tpa) was assayed discontinuously at $30^{\circ} \mathrm{C}$ as the pyruvate-dependent disappearance of taurine concomitant with the formation of alanine (Brüggemann et al. 2004). Xsc was routinely assayed by GC as the phosphate-dependent release of acetate after acidification to hydrolyze the acetyl phosphate formed; on occasion, the colorimetric determination of acetyl phosphate, or the formation of sulfite was used (Ruff et al. 2003). Sulfite dehydrogenase was assayed spectrophotometrically with $\mathrm{K}_{3} \mathrm{Fe}(\mathrm{CN})_{6}$ as electron acceptor (Reichenbecher et al. 1999). Phosphate acetyltransferase (Pta) was assayed photometrically as the HS-CoAdependent formation of acetyl-CoA (Bergmeyer et al. 1983). Isocitrate lyase was assayed as release of glyoxylate in a colorimetric assay (Dixon and Kornberg 1959). 
Analytical methods

Growth was followed as turbidity at $580 \mathrm{~nm}$ or quantified as protein in a Lowry-type reaction (Cook and Hütter 1981). Sulfate was determined turbidimetrically as a suspension of $\mathrm{BaSO}_{4}$ (Sörbo 1987). Sulfite was quantified as the fuchsin-derivative as described elsewhere (Denger et al. 2001). Ammonium ion was assayed colorimetrically by the Berthelot reaction (Gesellschaft Deutscher Chemiker 1996). Acetyl phosphate was determined chemically as iron(III) acetyl hydroxamate (Racker 1962). Acetate was quantified by GC (Laue et al. 1997) and occasionally confirmed by a specific enzymic reaction (Beutler 1984). Reversed phase HPLC was used to quantify taurine and alanine after derivatisation with 2,4-dinitrofluorobenzene (DNFB) (Laue et al. 1997), or to quantify free sulfoacetaldehyde after derivatisation with 2-(diphenylacetyl)indane-1,3-dione-1-hydrazone (DIH) (Cunningham et al. 1998). Unsuccessful attempts were made to derivatize $N$-acetyltaurine with DNFB, DIH, dabsylchloride (Hughes et al. 1987) or with 2,4-dinitrophenylhydrazine. Evidence for the identity of $\mathrm{N}$-acetyltaurine, for its complete degradation during growth or for the identity of taurine as a product of the $\mathrm{N}$-acetyltaurine amidase reaction was confirmed by MALDI-TOF-MS in the negative-ion mode (Tholey et al. 2002). Values of $K_{\mathrm{m}}$ were derived from plots of rate versus substrate concentration by fitting hyperbolic curves to these raw data in Microcal Origin 6.0 software. SDS-PAGE and staining were done by standard methods (Laemmli 1970). Standard methods were used to establish Gram reaction, catalase and cytochrome $c$ oxidase activity (Gerhardt et al. 1994). A 1,457-bp fragment of the 16S rRNA gene of strain NAT was amplified by PCR, sequenced and analyzed as described elsewhere (Brüggemann et al. 2004). A portion of the $x s c$-gene was amplified using degenerate PCR primers and sequenced as described previously (Weinitschke et al. 2006). Sequences were deposited at GenBank under the accession numbers AM180725 (the partial 16S rRNA gene) and AM180726 (the partial xsc-gene).

\section{Results and discussion}

Enrichments, isolation, identification and growth physiology of $D$. acidovorans NAT

Aerobic enrichment cultures able to utilize $\mathrm{N}$-acetyltaurine as either sole source of combined nitrogen or as sole source of carbon and energy were easily obtained from the three different inocula used: this indicates its widespread biodegradability. These cultures, which grew overnight, were plated on complex medium after the third transfer, and six pure cultures were obtained. One representative isolate (from forest soil), strain NAT, able to utilize $N$-acetyltaurine as a sole source of carbon and energy for growth, was chosen for further investigations. Strain NAT was a Gram-negative, motile, non spore-forming rod $(0.5-1 \times 2 \mu \mathrm{m}$ in size) which was catalase-positive and cytochrome- $c$ oxidase positive. The 1,457-bp fragment of the 16S rRNA gene of strain NAT was sequenced: it shared $99.6 \%$ identity of position with the corresponding gene of $D$. acidovorans IAM $12409^{\mathrm{T}}$. This tentative identification was compatible with physiological tests and the substrate range (see below), and strain NAT was deposited with the German Culture Collection (DSMZ, Braunschweig, Germany) as a strain of the B-Proteobacterium D. acidovorans (DSM 17854).

Delftia acidovorans NAT grew exponentially with $\mathrm{N}$-acetyltaurine as sole source of carbon with a specific growth rate of $0.27 \mathrm{~h}^{-1}$ (Fig. 2a). Attempts to quantify $\mathrm{N}$-acetyltaurine by standard derivatizations of the oxogroup or of the amino-group failed, so mass spectrometry in the negative ion mode was used to prove complete substrate degradation. The substrate was detected $\left(m / z=166[M-1]^{-}\right)$in freshly inoculated growth medium, but none remained after growth (not shown). Sulfate was formed concomitantly with growth; no sulfite was detected (Fig. 2b). Transient release of low concentrations $(\leq 0.3 \mathrm{mM})$ of taurine and acetate was also observed (Fig. 2b). Protein and the ammonium and sulfate ions were quantified in outgrown cultures which had contained different initial concentrations of $\mathrm{N}$-acetyltaurine as sole source of carbon and nitrogen for growth. The molar growth yield was determined to be $22 \mathrm{~g}$ protein per mol $\mathrm{N}$-acetyltaurine, i.e. $5.5 \mathrm{~g}$ protein per mol carbon, which indicated dissimilation of all four carbon atoms of $N$-acetyltaurine (Cook 1987). About $1.1 \mathrm{~mol}$ sulfate and $0.7 \mathrm{~mol}$ ammonium per mol of $N$-acetyltaurine were recovered (not shown), and about $0.3 \mathrm{~mol}$ nitrogen was calculated to be in the biomass. These data were interpreted to represent mass balance for the carbon, nitrogen and sulfur moieties in $\mathrm{N}$-acetyltaurine. The values for the specific growth rate and for the molar growth yield were then used to calculate the specific turnover rate for $\mathrm{N}$-acetyltaurine (3.4 mkat $(\mathrm{kg} \text { protein })^{-1}$ ) during growth.

Two putative intermediates in the degradation pathway of $\mathrm{N}$-acetyltaurine, acetate and taurine (Fig. 2b), and related compounds were tested as sole 

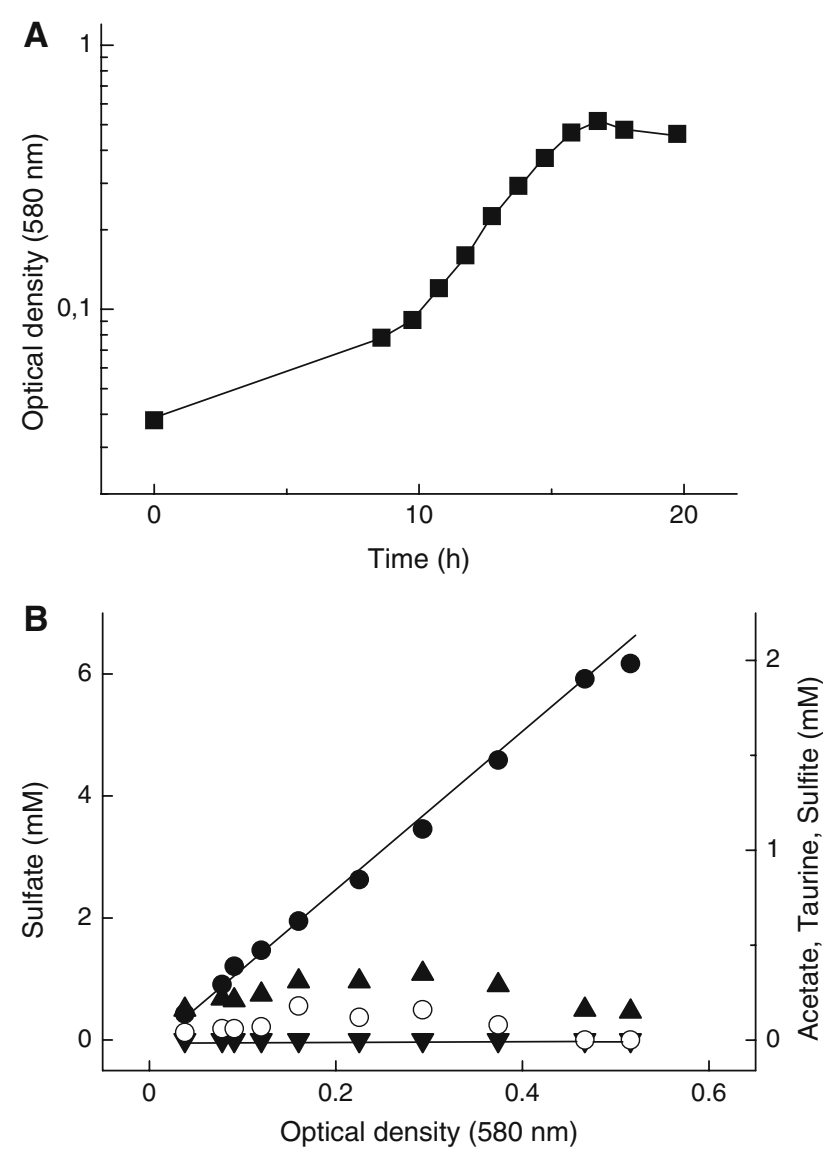

Fig. 2 Growth of D. acidovorans NAT with $N$-acetyltaurine. a Semi-logarithmic graph of growth. b Product formation plotted against growth. Key: filled circle, sulfate; filled triangle, acetate; open circle, taurine; filled inverted triangle, sulfite. Note that an expanded scale is used for the transient (and undetected) products

sources of carbon for growth of $D$. acidovorans NAT. The organism utilized taurine, acetate and acetamide, D-fructose, mannitol, phenylacetate, maleate, $\beta$-alanine, glycolate, L-histidine, L-phenylalanine or benzoate (at $1 \mathrm{mM}$; no growth at $4 \mathrm{mM}$ ) but not L-cysteate, 3 -aminopropanesulfonate, $N$-methyltaurine or glucose. This pattern of utilization of carbon sources, particularly those chosen from Holt et al. (1994), was consistent with the pattern of utilization given for Pseudomonas acidovorans by Palleroni (1984), but not with the data of Holt et al. (1994). We presume that a mistake was made in the transfer of data when the genus was renamed twice (Wen et al. 1999), and that the early experiments were done with an inhibitory concentration of benzoate. We also tested whether the sulfonates could serve as sole sources of combined nitrogen for growth (cf. Weinitschke et al. 2005). D. acidovorans NAT assimilated nitrogen from $\mathrm{N}$-acetyltaurine, taurine or acetamide, but not from cysteate, 3-aminopropanesulfonate or $\mathrm{N}$-methyltaurine.
The degradative intermediates and the pathway of $N$-acetyltaurine dissimilation

Two hypotheses for the first step in the degradation of $N$-acetyltaurine by $D$. acidovorans NAT had been considered (Introduction), but, in light of the transients observed during growth (Fig. 2b), hydrolysis to acetate and taurine by an amidase was considered more likely. Incubation of $\mathrm{N}$-acetyltaurine with crude extracts of $\mathrm{N}$-acetyltaurine-grown cells yielded stoichiometric amounts of acetate and taurine (Fig. 3). No electronacceptor or amino-group-acceptor had to be added, so the reaction was interpreted to be hydrolytic. The specific activity of this amidase was high (39 mkat kg protein ${ }^{-1}$, Table 1), certainly enough to explain the $3.4 \mathrm{mkat} / \mathrm{kg}$ protein required for growth (see above). Negligible activity was detected in crude extracts from acetate- or taurine-grown cells (Fig. 3, Table 1): the enzyme is, thus, inducible. The $K_{\mathrm{m}}$-value of the enzyme for $\mathrm{N}$-acetyltaurine was calculated to be $2.4 \pm 0.4 \mathrm{mM}$. Amidases are known for their broad substrate specificity (Webb 1992), and we were concerned that we might be working with a known amidase in $D$. acidovorans, the broad substrate-range, stereospecific ketoprofen-amide amidase of Hayashi et al. (1997). However, acetamide and valeramide were poor substrates for $\mathrm{N}$-acetyltaurine amidase, whereas they were good substrates for ketoprofen-amide amidase (Hayashi et al. 1997). There is obviously a novel $\mathrm{N}$-acetyltaurine amidase in strain NAT. This hydrolase, acting on a carbon-nitrogen bond other than a peptide bond, presumably belongs to EC 3.5.1.- and has as a formal name $N$-acetyltaurine amidohydrolase.

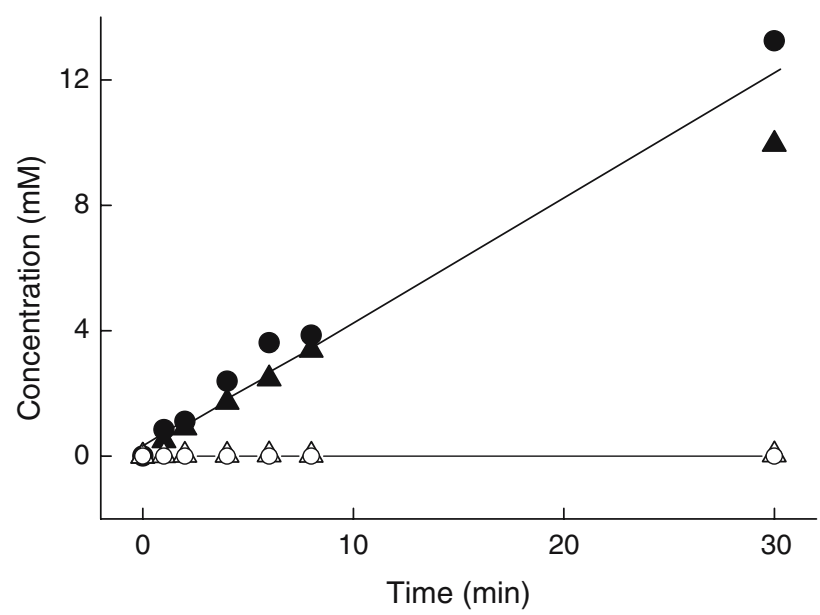

Fig. 3 Product formation of the $N$-acetyltaurine amidase reaction in extracts of $N$-acetyltaurine-grown cells $\left(0.3 \mathrm{mg} \mathrm{ml}^{-1}\right)$ (filled symbols) or acetate-grown cells $\left(0.6 \mathrm{mg} \mathrm{ml}^{-1}\right)$ (open symbols). Key: filled circle, open circle, taurine; filled triangle, open triangle, acetate 
Two potential taurine-degrading enzymes were tested. No taurine:pyruvate aminotransferase was detected (Table 1). In contrast, Tdh activity was found in extracts of taurine-grown cells (Table 1, Fig. 1) with DCPIP as the electron acceptor; beef heart cytochrome $c$ did not function as an electron acceptor. A lower activity of Tdh was detected in extracts of $\mathrm{N}$-acetyltaurine-grown cells and none in extracts of acetategrown cells, which was interpreted as induction of this enzyme during growth with taurine or $\mathrm{N}$-acetyltaurine. The enzyme assay measures electron transfer to DCPIP, and confirmation was sought that sulfoacetaldehyde was, indeed, formed. This product was detected quantitatively in the reaction mixtures with extracts of taurine-grown cells and with extracts of $\mathrm{N}$-acetyltaurine-grown cells. The ready generation of sulfoacetaldehyde in extracts grown with $N$-acetyltaurine, compared with the poor specific activity of the enzyme with DCPIP as substrate in Table 1, suggests that the assay with DCPIP underestimates the activity present. It was also possible to couple the activities of Tdh and Xsc (see below), and to assay the acetyl phosphate, after acidification, as acetic acid. Here, too, a high level of Tdh activity in $\mathrm{N}$-acetyltaurine-grown cells was indicated. The natural electron acceptor is presumably native cytochrome $c$ (Denger et al. 2004b; Weinitschke et al. 2006), and its availability would simplify work on Tdh.

Xsc (Fig. 1), the key enzyme in the degradation of $\mathrm{C}_{2}$-sulfonates which are degraded via sulfoacetaldehyde (Cook and Denger 2002), was detected as an inducible enzyme in extracts of taurine- or of $N$-acetyltaurine-grown cells (Table 1 ). Xsc in other organisms, irrespective of the Xsc-subgroup involved, is a $63-\mathrm{kDa}$ protein, which is expressed at $5-20 \%$ of soluble protein (Denger et al. 2001, 2004a; Ruff et al. 2003; Brüggemann et al. 2004). Proteins in crude extracts of differently-grown cells of $D$. acidovorans NAT were separated by SDS-PAGE, and the predicted (Table 1), inducible 63-kDa protein was observed (not shown). PCR with degenerate primers for $x s c$ revealed an amplicon of the anticipated length $(658 \mathrm{bp})$. Sequencing of this product and comparison of the deduced partial amino acid sequence with the databases showed high identity of position (75-93\%) with corresponding sequences of Xsc subgroup 1 (Ruff et al. 2003), consistent with the phylogenetic position of $D$. acidovorans NAT in the B-Proteobacteria.

The products of the Xsc reaction are acetyl phosphate and sulfite (Fig. 1), whereas the organism releases sulfate into the medium (Fig. 2). Correspondingly, an inducible sulfite dehydrogenase was found in extracts of cells grown with taurine or $\mathrm{N}$-acetyltaurine (Table 1): the ferricyanide-coupled and not the cytochrome-c-coupled assay gave activity (see Reichenbecher et al. 1999). The fate of the acetyl phosphate is presumably conversion by Pta to acetyl CoA (Table 1, Fig. 1). A further molecule of acetyl $\mathrm{CoA}$ is anticipated from the acetate molecule released by the amidase reaction (Fig. 1). This acetyl CoA is presumably channeled to the Krebs cycle, fatty acid synthesis and the glyoxylate cycle, whose key enzyme, isocitrate lyase, was observed (Table 1).

$\mathrm{N}$-acetyltaurine is another natural sulfonate, whose degradation is channeled via sulfoacetaldehyde (Cook and Denger 2002; Weinitschke et al. 2006). This emphasizes the importance of sulfoacetaldehyde acetyltransferases, because the $x s c$-gene is being found in increasing numbers in genome projects including organisms from marine habitats, even a dinoflagellate [GenBank accession number AAW79287; incorrectly annotated as an acetolactate synthase by Patron et al. (2005)]. This again indicates the importance of sulfonates in the nutrition of terrestrial and marine microbes.

Acknowledgments The project was supported by funds from the University of Konstanz.

\section{References}

Bergmeyer HU, Graßl M, Walter E-M (1983) Phosphotransacetylase. In: Bergmeyer HU (ed) Methods of enzymatic analysis, 3rd edn. Verlag Chemie, Weinheim, pp 295-296

Beutler H-O (1984) Acetate: determination with acetyl-CoA synthase. In: Bergmeyer HU (ed) Methods of enzymic analysis, 3rd edn. Verlag Chemie, Weinheim, pp 639-645

Brüggemann C, Denger K, Cook AM, Ruff J (2004) Enzymes and genes of taurine and isethionate dissimilation in Paracoccus denitrificans. Microbiology (Reading UK) 150:805816

Clayden J, Greeves N, Warren S, Wothers P (2001) Organic chemistry. Oxford University Press, Oxford, pp 420-425

Cook AM (1987) Biodegradation of $s$-triazine xenobiotics. FEMS Microbiol Rev 46:93-116

Cook AM, Denger K (2002) Dissimilation of the $C_{2}$ sulfonates. Arch Microbiol 179:1-6

Cook AM, Denger K (2006) Metabolism of taurine in microorganisms: a primer in molecular diversity? Adv Exp Med Biol 583:3-13

Cook AM, Hütter R (1981) s-Triazines as nitrogen sources for bacteria. J Agric Food Chem 29:1135-1143

Cunningham C, Tipton KF, Dixon HBF (1998) Conversion of taurine into $\mathrm{N}$-chlorotaurine (taurine chloramine) and sulphoacetaldehyde in response to oxidative stress. Biochem $\mathbf{J}$ 330:939-945

Denger K, Ruff J, Rein U, Cook AM (2001) Sulfoacetaldehyde sulfo-lyase [EC 4.4.1.12] from Desulfonispora thiosulfatigenes: purification, properties and primary sequence. Biochem J 357:581-586 
Denger K, Ruff J, Schleheck D, Cook AM (2004a) Rhodococcus opacus expresses the $x s c$ gene to utilize taurine as a carbon source or as a nitrogen source but not as a sulfur source. Microbiology (Reading UK) 150:1859-1867

Denger K, Smits THM, Cook AM (2006) L-Cysteate sulfo-lyase, a widespread, pyridoxal 5'-phosphate-coupled desulfonative enzyme purified from Silicibacter pomeroyi DSS $-3^{\mathrm{T}}$. Biochem J 394:657-664

Denger K, Weinitschke S, Hollemeyer K, Cook AM (2004b) Sulfoacetate generated by Rhodopseudomonas palustris from taurine. Arch Microbiol 182:254-258

Dixon GH, Kornberg HL (1959) Assay methods for key enzymes of the glyoxylate cycle. Biochem J 72:3P

Fujimoto D, Koyama T, Tamiya N (1968) $N$-Acetyl- $\beta$-alanine deacetylase in hog kidney. Biochim Biophys Acta 167:407413

Gerhardt P, Murray RGE, Wood WA, Krieg NR (1994) Methods for general and molecular bacteriology. American Society for Microbiology, Washington

Gesellschaft Deutscher Chemiker (1996) German standard methods for the laboratory examination of water, waste water and sludge. Verlag Chemie, Weinheim

Gorzynska AK, Denger K, Cook AM, Smits THM (2006) Inducible transcription of genes involved in taurine uptake and dissimilation by Silicibacter pomeroyi DSS $-3^{\mathrm{T}}$. Arch Microbiol 182:402-406

Hayashi T, Yamamoto K, Matsuo A, Otsubo K, Muramatsu S, Matsuda A, Komatsu K-E (1997) Characterization and cloning of an enantioselective amidase from Comamonas acidovorans KPO-2771-4. J Ferment Bioeng 83:139-145

Higgins LE, Townley MA, Tillinghast EK, Rankin MA (2001) Variation in the chemical composition of orb webs built by the spider Nephila clavipes (Araneae, Tetragnathidae). J Arachnol 29:82-94

Holt JG, Krieg NR, Sneath PHA, Staley JT, Williams ST (1994) Bergey's manual of determinative bacteriology, 9th edn. Williams \& Wilkins, Baltimore

Hughes GJ, Frutiger S, Fonck C (1987) Quantitative high-performance liquid chromatographic analysis of Dabsyl-amino acids within 14 min. J Chromatogr 389:327-333

Huxtable RJ (1992) Physiological actions of taurine. Physiol Rev 72:101-163

Kim G-B, Miyamoto CM, Meighen EA, Lee BH (2004) Cloning and characterization of the bile salt hydrolase genes $(b s h)$ from Bifidobacterium bifidum strains. Appl Environ Microbiol 70:5603-5612

Laemmli UK (1970) Cleavage of structural proteins during the assembly of the head of bacteriophage T4. Nat Lond 227:680-685

Laue H, Denger K, Cook AM (1997) Taurine reduction in anaerobic respiration of Bilophila wadsworthia RZATAU. Appl Environ Microbiol 63:2016-2021

Palleroni NJ (1984) Pseudomonadaceae. In: Krieg NR (ed) Bergey's manual of systematic bacteriology. Williams \& Wilkins, Baltimore, pp 141-199
Patron NJ, Waller RF, Archibald JM, Keeling PJ (2005) Complex protein targeting to dinoflagellate plastids. J Mol Biol 348:1015-1024

Racker E (1962) Fructose-6-phosphate phosphoketolase from Acetobacter xylinum. Methods Enzymol 5:276-280

Reichenbecher W, Kelly DP, Murrell JC (1999) Desulfonation of propanesulfonic acid by Comamonas acidovorans strain P53: evidence for an alkanesulfonate sulfonatase and an atypical sulfite dehydrogenase. Arch Microbiol 172:387-392

Rein U, Gueta R, Denger K, Ruff J, Hollemeyer K, Cook AM (2005) Dissimilation of cysteate via 3-sulfolactate sulfo-lyase and a sulfate exporter in Paracoccus pantotrophus NKNCYSA. Microbiology (Reading UK) 151:737-747

Ruff J, Denger K, Cook AM (2003) Sulphoacetaldehyde acetyltransferase yields acetyl phosphate: purification from Alcaligenes defragrans and gene clusters in taurine degradation. Biochem J 369:275-285

Sörbo B (1987) Sulfate: turbidimetric and nephelometric methods. Methods Enzymol 143:3-6

Teraoka M (1925) Methylation and acylation of taurine. HoppeSeyler's Z Physiol Chem 145:238-243

Tholey A, Wittmann C, Kang MJ, Bungert D, Hollemeyer K, Heinzle E (2002) Derivatization of small biomolecules for optimized matrix-assisted laser desorption/ionization mass spectrometry. J Mass Spectrom 37:963-973

Thurnheer T, Köhler T, Cook AM, Leisinger T (1986) Orthanilic acid and analogues as carbon sources for bacteria: growth physiology and enzymic desulphonation. J Gen Microbiol 132:1215-1220

Vollrath F, Fairbrother WJ, Williams RJP, Tillinghast EK, Bernstein DT, Gallagher KS, Townley MA (1990) Compounds in the droplets of the orb spider's viscid spiral. Nat Lond 345:526-528

Webb EC (1992) Enzyme nomenclature 1992: recommendations of the Nomenclature Committee of the International Union of Biochemistry and Molecular Biology. Academic, San Diego, p 306

Weinitschke S, Denger K, Smits THM, Hollemeyer K, Cook AM (2006) The sulfonated osmolyte $N$-methyltaurine is dissimilated by Alcaligenes faecalis and by Paracoccus versutus with release of methylamine. Microbiology (Reading UK) 152:1179-1186

Weinitschke S, Styp von Rekowski K, Denger K, Cook AM (2005) Sulfoacetaldehyde is excreted quantitatively by $A c i$ netobacter calcoaceticus SW1 during growth with taurine as sole source of nitrogen. Microbiology (Reading UK) 151:1285-1290

Wen A, Fegan M, Hayward C, Chakraborty S, Sly LI (1999) Phylogenetic relationships among members of the Comamonadaceae, and description of Delftia acidovorans (den Dooren de Jong 1926 and Tamaoka et al. 1987) gen nov, comb nov. Int J Syst Bacteriol 49:567-576 